\title{
Trends in arrivals and prices of cocoons in Shirahatti market at Haveri district
}

\section{ROOPA HOSALI AND C. MURTHY}

\begin{abstract}
The study was conducted in Haveri district of Karnataka state. Where mulberry area of 947 hectares and cocoon production of $680.511 \mathrm{M}$ tonnes, respectively during 2013-14 was obsered. The study was conducted to Trends in arrivals and prices of cocoons in Shirahatti market at Haveri District. In Haveri district Shirahatti taluka market were selected. The trend was computed in order to ascertain the long run movements of market arrivals of cocoon in the Shirahatti market.The trend in arrivals and prices of multivariate cocoon in Shirahatti market over the year were found to be significant at one per cent probability level with $\mathrm{R}^{2}$ value of 0.42 and 0.58 , respectively. In order to ascertain the long term movement of cocoon price in the Shirahatti market the data relating to prices of cocoon were subjected to non linear (exponential) trend equation analysis.
\end{abstract}

KEY WORDS : Trends, Arrivals, Prices, Cocoons

How to cite this paper : Hosali, Roopa and Murthy, C. (2015). Trends in arrivals and prices of cocoons in Shirahatti market at Haveri district. Internat. J. Com. \& Bus. Manage, 8(1): 131-134.

\section{MEMBERS OF THE RESEARCH FORUM}

Correspondence to:

ROOPA HOSALI, Department of Agribusiness Management, College of Agriculture, University of Agricultural Sciences, DHARWAD (KARNATAKA) INDIA

Email: roopa.hosali88@gmail.com

Authors' affiliations:

C. MURTHY, Department of Agribusiness Management, College of Agriculture, University of Agricultural Sciences, DHARWAD (KARNATAKA) INDIA 